\title{
SISTEM PAKAR DIAGNOSA PENYAKIT TANAMAN KEDELAI MENGGUNAKAN METODE FORWARD CHAINING BERBASIS WEB
}

\author{
Ahmad Fahrudi Setiawan ${ }^{1)}$, Ratih Noviana Wahidah ${ }^{2)}$ \\ Institut Tekonologi Nasional Malang
}

\begin{abstract}
Abstrak: Tanaman kedelai merupakan salah satu tanaman kacang-kacangan yang tergolong penting serta memiliki pengaruh terhadap perekonomian negara. Kebutuhan kedelai mengalami peningkatan setiap tahunnya, akan tetapi kurang didukung dengan peningkatan produksi kedelai dalam negeri, sehingga menyebabkan impor kedelai pun meningkat. Namun dalam perkembangannya keterbatasan pengetahuan yang berkaitan dengan kendala produksi kedelai dan keberadaan penyakit kedelai sangat diperlukan untuk peningkatan produksi kedelai. Dengan semakin majunya teknologi dan informasi di dunia saat ini, maka membawa pengaruh dalam kemajuan perkembangan teknologi yang mendorong seseorang untuk membuat suatu aplikasi sistem pakar diagnosa penyakit tanaman kedelai menggunakan metode Forward Chaining untuk memudahkan para petani mengetahui penyakit apa saja yang mampu menyerang tanaman kedelai dengan mudah tanpa harus mengeluarkan biaya yang banyak untuk konsultasikan tentang penyakit apa yang terjadi. Dalam sistem pakar ini menggunakan metode Forward Chaining. Dimana metode ini mencari terlebih dahulu sebuah informasi yang ada dan penggabungan rule untuk menghasilkan suatu kesimpuan atau tujuan. Dengan adanya sistem pakar ini, diharapkan dapat membantu para petani dalam mendeteksi penyakit pada kedelai , serta dapat mempercepat waktu pengerjaan diagnosa penyakitnya serta dapat memberikan solusinya.
\end{abstract}

Kata kunci: Sistem Pakar, Forward Chaining, Diagnosa Penyakit Tanaman Kedelai, Website

\section{PENDAHULUAN}

\section{a. Latar Belakang}

Kedelai (Glycine max) merupakan salah satu jenis tanaman kekacangan semusim. Meskipun produksi kedelai terutama berada di daerah sedang, seperti Brazilia yang merupakan salah satu produsen kedelai utama, tentu tidak menutup kemungkinan produksi yang sangat besar dilakukan di daerah tropika, seperti Indonesia. Kedelai menjadi tanaman penghasil bahan makanan penting, di beberapa negara Asia, baik sebagai pakan ternak, penghasil minyak, maupun penyubur tanah. Namun ada beberapa jenis penyakit pada tanaman kedelai yang harus diketahui. Penyakit pada tanamn kedelai dapat dibedakan menjadi dua kelompok besar yaitu penyakit biotik dan abiotik. Usaha terbaik untuk menangulangi penyakit tanaman kedelai dengan cara pemantauan, varietas tahan penyakit, pengendalian penyakit dengan budidaya, serta pengendalian secara mekanis, hayati, nabati dan secara kimia.

Sistem pakar hanya diketahui oleh seorang pakar dan para ahli dari bidang nya. Para petani awam dan petani yang berada pada daerah pelosok belum memahami penyakit yang dialami oleh tanaman kedelai. Petani hanya mengetahui 
penyakit yang dialami oleh tanaman kedelai dikarenakan serangan serangga, jamur, dan cuaca. Sehingga para petani selalu menyemprotkan tanaman kedelai dengan insektisida. Tetapi dengan menyemprotkan insektisida pada tanaman tidak dapat sepenuhnya mengurangi serangan pada tanaman, sikap yang tepat dalam menghadapi penyakit pada tanaman adalah menetapkan pencegahan penyakit dengan baik untuk penanaman selanjutnya dengan memperhatikan pengolahan tanah, pemilihan bibit kedelai, pemupukan, pengobatan tanaman, dan perawatan tanaman.

Metode pada sistem pakar sangat penting untuk mendiagnosa penyakit. Dengan mendiagnosa gejala masing-masing tanaman yaitu kedelai, mencocokkannya dengan aturan yang ada, dan menghasilkan diagnosis berdasarkan basis pengetahuan. Pada sistem pakar terdapat banyak metode yaitu forward chaining, backward chaining. Peneliti menggunakan metode forward chaining.

Dengan menggunakan sistem pakar diharapkan dapat mempercepat dalam mendiagnosa suatu jenis penyakit tanaman kedelai, sehingga dapat dengan mudah diketahui jenis penyakit yang sedang menjangkit tersebut. Dari uraian di atas, maka penulis tertarik untuk membangun sebuah aplikasi sistem pakar diagnosa penyakit tanaman kedelai dimana aplikasi tersebut diharapkan dapat membantu memberikan solusi alternatif untuk para petani dalam menangani gejala awal penyakit pada kedelai. Oleh sebab itu, penulis akan menciptakan suatu aplikasi berbasis website yang dapat menjawab permasalahan tersebut dengan basis website.

\section{b. Rumusan Masalah}

Berdasarkan latar belakang yang telah dikemukakan sebelumnya, maka penuls akan merumuskan masalah yang akan dibahas sebagai berikut.

1. Bagaimana mengimplementasikan sistem pakar diagnosa penyakit tanaman kedelai pada bahasa pemrograman $P H P$ dan $M y S Q L$ untuk database server

2. Bagaimana diagnosa penyakit pada tanaman kedelai dengan merancang bangun sistem berbasis website?

3. Bagaimana mengimpenlementasikan metode forward chaining pada sistem pakar diagnosa penyakit tanaman kedelai ?

\section{c. Batasan Masalah}

Dalam penyusunan skripsi agar menjadi sistematis dan mudah dimengerti, maka akan diterapkan beberapa batasan masalah. Batasan-batasan masalah itu antara lain sebagai berikut.

1. Sistem yang di bangun ini mempunyai 13 penyakit tanaman kedelai yaitu karat daun, bisul bakteri, antroknose, downy mildew, target spot, rebah kecambah, busuk daun, batang dan polong, hawar batang, virus mozaik, kahat nitrogen $(\mathrm{N})$, kahat fosfor $(\mathrm{P})$, kahat kalium $(\mathrm{K})$, kahat kalsium $(\mathrm{Ca})$, dan kahat magnesium $(\mathrm{Mg})$.

2. Sistem yang dibangun ini mempunyai 59 gejala dari 13 penyakit yang ada pada tanaman kedelai.

3. Sistem ini menggunakan metode Certainty Factor dan akan dibangun menggunakan Forward Chaining. 
4. Sistem dibuat dengan bahasa pemrograman PHP dan Database yang digunakan adalah $M y S Q L$.

\section{d. Tujuan}

Adapun tujuan yang ingin dicapai dari pembuatan aplikasi ini adalah sebagai berikut.

1. Mengimplementasi kan sistem pakar diagnosa penyakit tanaman kedelai ke dalam bahasa pemrograman $P H P$ dan $M y S Q L$ untuk database server.

2. Merancang dan membangun suatu aplikasi sistem pakar yang dapat memberikan informasi gejala atau diagnosa penyakit pada tanaman kedelai berbasis website.

3. Mengimplementasi kan metode forward chaining pada sistem pakar diagnosa penyakit tanaman kedelai.

\section{TINJAUAN PUSTAKA}

Sistem pakar peyakit tanaman kedelai akan lebih efektif dan efisien dengan komputerisasi yang tepat. Sistem pakar peyakit tanaman kedelai mampu memberikan kecepatan hasil diagnosa, pengolahan data yang akurat, sehingga data bisa langsung digunakan dan mengetahui hasil dari diagnosa penyakit tanmana kedelai dari beberapa gejala yang diinputkan.

Sistem pakar peyakit tanaman kedelai ini sebelumya sudah banyak dibuat, tetapi tempat dan program aplikasinya yang di gunakan berbeda-beda. Adapun sistem informasi yang berkaitan dengan penjualan dan pembelian yang pernah dibuat adalah sebagai berikut :

Aliman (2012) Judul penelitian ini adalah aplikasi sistem pakar untuk mendiagnosa penyakit pada tanaman kedelai berbasis website. Dalam penelitian ini sistem yang dibuat mampu dalam menginputkan, mengubah, serta menhapus data atau menampilkan data gejala, data penyakit. Namun pada aplikasi ini hanya menggunakan metode forward chaining sehingga dalam hal keakuratan data kurang dapat dipastikan.

Mahendra (2014) Judul penelitian ini adalah penerapan teorema bayes untuk identifikasi penyakit pada tanaman kedelai. Dalam penelitian ini sistem yang dibuat mampu dalam menginputkan data, mengubah data ataupun menghapus data, proses diagnosa dengan menggunakan metode bayes dimana keakuratan sistem sudah dapat dipastikan dengan adanya nilai keakuratan. Namun pada aplikasi ini menggunakan 9 penyakit dan 19 gejala yang dirasa kurang sehingga perlu adanya penambahan data berupa penyakit mauppun gejala agar hasil diagnosa yang dihasilkan lebih akurat.

Pratama (2013) Judul penelitian ini adalah rancang bangun aplikasi sistem pakar untuk menentukan penyakit pada tanaman kedelai. Dalam penelitian ini sistem yang dibuat mampu dalam menginputkan data, mengubah data serta menghapus data yang ada pada admin. Namun pada penelitian ini belum ada bukti keakuratan sistem agar data lebih bisa dipertimbangkan hasilnya dan juga pada 
sistem ini menggunakan 9 jenis penyakit tanaman kedelai yang dirasa kurang lengkap.

Destarianto (2013) Judul penelitian ini adalah perancangan sistem pakar untuk mengindentifikasi penyakit pada tanaman semangka dengan menggunakan metode certainty factor. Dalam penelitian ini sistem yang dibuat mampu dalam menginputkan data, mengubah data serta menghapus data yang ada pada admin. Pada sistem ini sudah cukup akurat dengan adanya certainty factor untuk memastikan tingkat kepastiannya namun pada sistem ini hanya ada dua penyakit jadi perlu dipertimbangkan untuk menambahkan jenis penyakitnya serta juga dalam tampilan bisa ditambahkan perincian misalnya langkah penanganan dan disertai gambar.

Dalam tinjauan pustaka yang telah di lakukan banyaknya penelitianpenelitian mahasiswa akan sistem pakar diagnosa penyakit tanaman kedelai yang kurang akurat maka sistem pakar diagnosa penyakit kedelai yang akan dibangun dalam penelitian ini adalah sistem pakar diagnosa penyakit tanaman kedelai menggunakan metode forward chaining dengan berbasis web.

\section{a. Studi Literatur}

\section{METODE PENELITIAN}

Pada tahap ini dipelajari literature dan perencanaan serta konsep awal untuk membentuk program yang akan dibuat yaitu didapat dari pakar, referensi buku, internet, maupun sumber-sumber yang lain.

\section{b. Pengumpulan Data dan Analisis}

Pada tahap ini adalah proses pengumpulan data yang dibutuhkan untuk pembuatan program, serta melakukan analisa atau pengamatan pada data yang sudah terkumpul untuk selanjutnya diolah lebih lanjut.

\section{c. Analisis dan Perancangan Sistem}

1. Perancangan Sistem Pendukung Keputusan Menggunakan Metode Forward Chaining

Pada Gambar 1 berikut ini merupakan Flowchart sistem pada Sistem Pakar Diagnosa Penyakit Tanaman Kedelai.

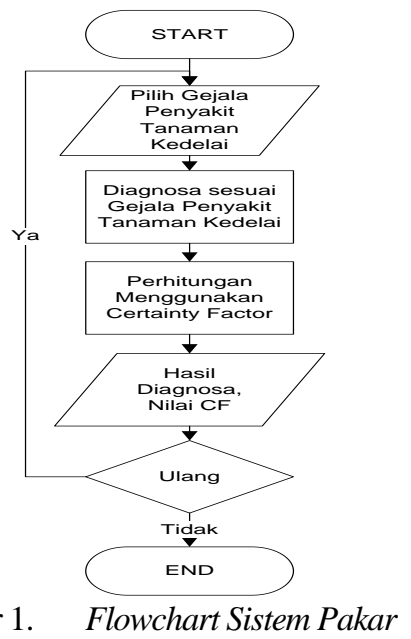


Pada Gambar 2 ini merupakan Flowchart Perhitungan Certainty Factor yang ada pada Sistem Pakar Diagnosa Tanaman Kedelai.

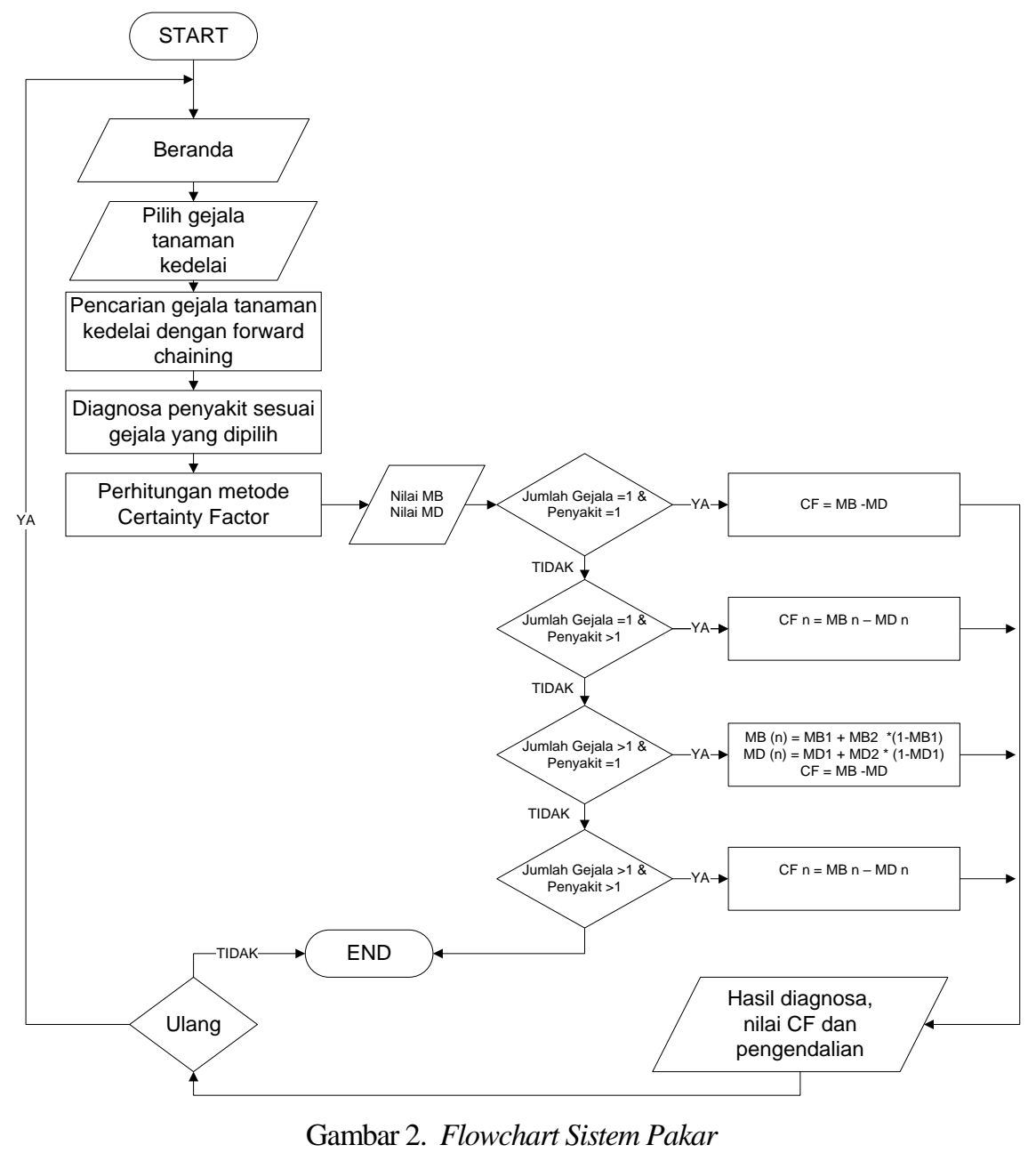

\section{Bagan Struktur Menu Aplikasi}

Bagan struktur menu menggambarkan menu yang dapat diakses oleh user dan admin Pada Gambar 3 ditampilkan struktur menu untuk user.

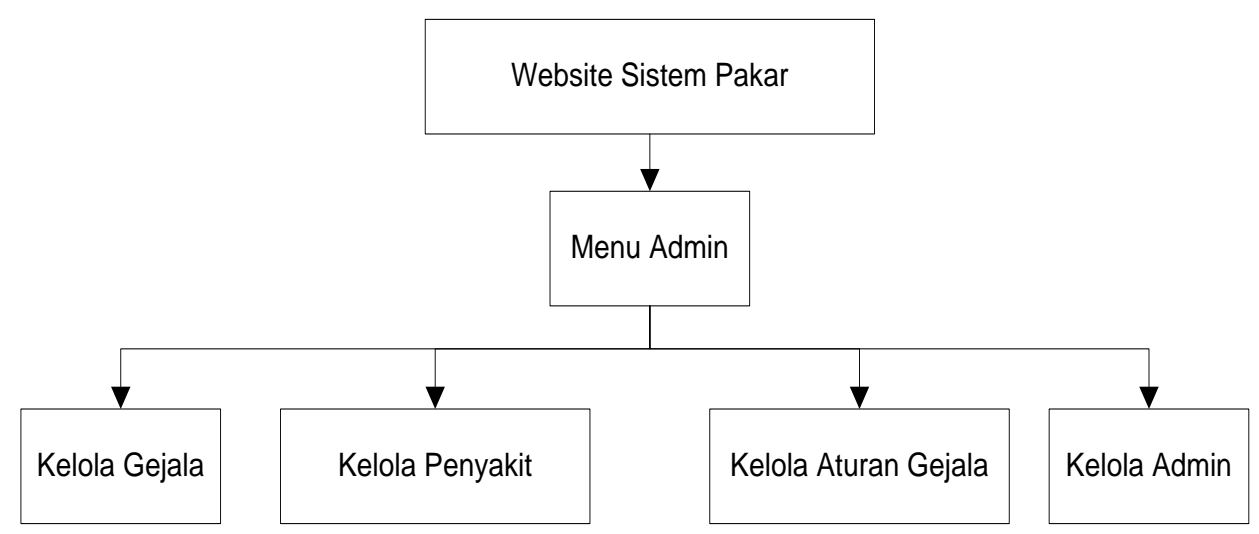

Gambar 3. Struktur menu user 
Pada Gambar 4 ditampilkan perancangan struktur menu untuk admin.

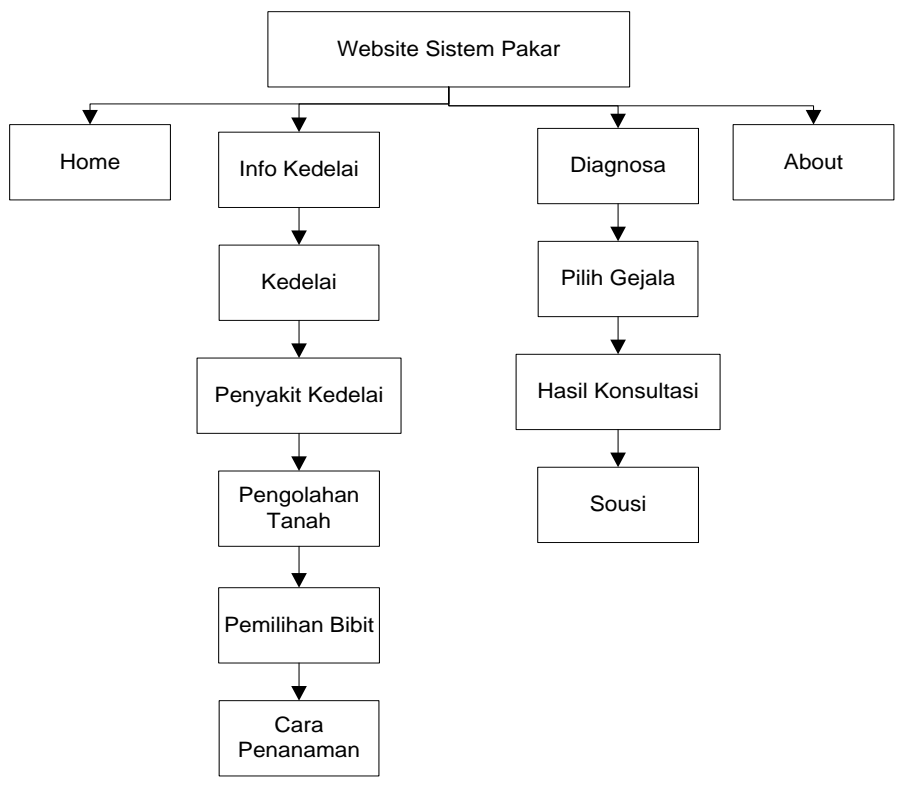

Gambar 4. Struktur Menu Admin

\section{Data Flow Diagram}

a) DFD Level 0

Pada Gambar 5 menunjukkan DFD level 0 yang merupakan gambaran dasar dari sistem yang akan dibangun dimana dalam sistem ini terdapat 2 entitas yaitu user dan admin.

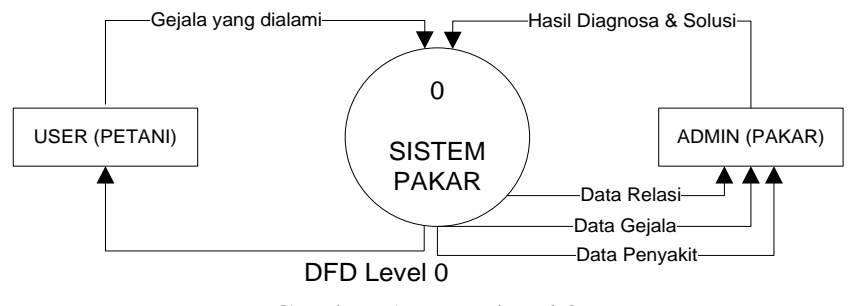

Gambar 5. DFD level 0

b) DFD Level 1

Pada Gambar 6 merupakan DFD level 1 ini memiliki 2 proses yaitu proses manajemen data dan diagnosa. Proses-proses tersebut saling berhubungan.

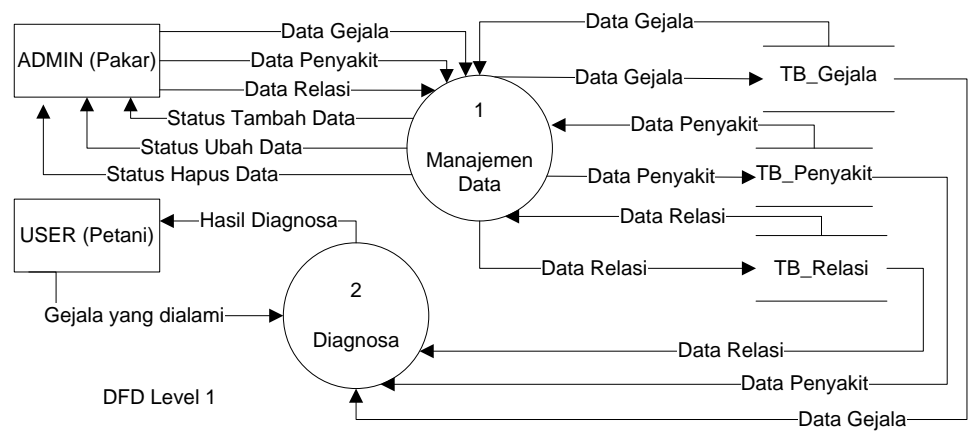

Gambar 6. DFD level 1 


\section{Flowchart User}

a) Flowchart User

Pada Gambar 7 berikut ini merupakan flowchart user.

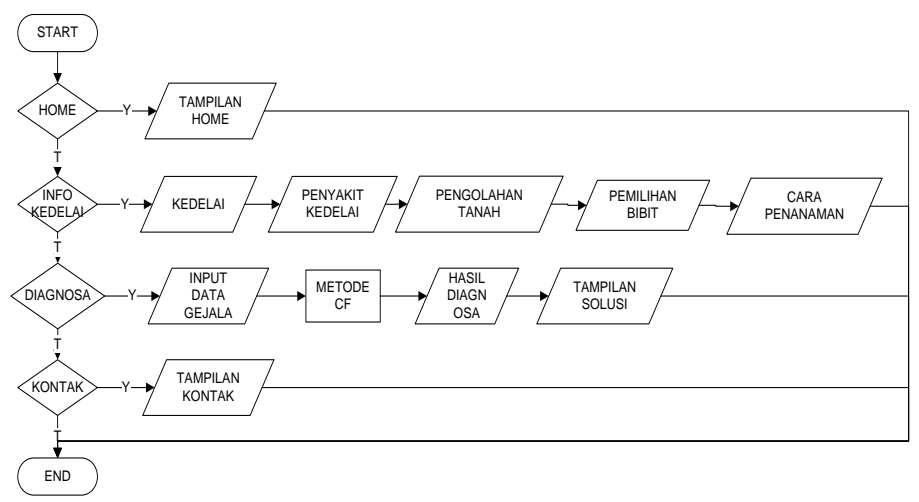

Gambar 7. Flowchart user

b) Flowchart Admin

Pada Gambar 8 berikut ini merupakan flowchart admin.

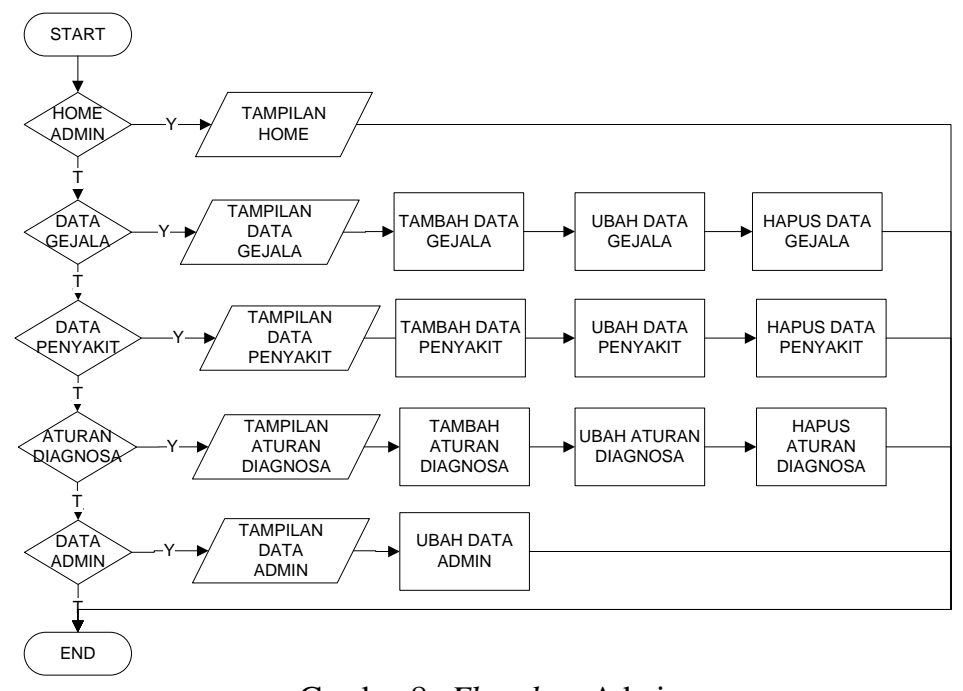

Gambar 8. Flowchart Admin

\section{d. Pembuatan Program}

Setelah tahap perancangan sistem maka tahap selanjutnya adalah pembuatan program. Pada tahap ini sistem yang sebelumnya telah dibuat akan diterapkan pada program yang akan dibuat. Pembuatan program ini menggunakan pemrograman $P H P$ dan menggunakan certainty factor sebagai metode penalaran pada program ini.

\section{e. Uji Coba Program}

Setelah program selesai dibuat maka dilakukan pengujian program untuk mengetahui apakah program tersebut telah bekerja dengan benar dan sesuai dengan sistem yang dibuat.

\section{f. Pembuatan Kesimpulan}

Pada tahap akhir ini adalah pembuatan kesimpulan atau ringkasan dari skripsi ini dan kesimpulan tentang program yang telah dibuat. 


\section{HASIL DAN PEMBAHASAN}

Setelah persiapan selesai disusun dan program aplikasi juga telah dibangun, maka tahap selanjutnya adalah menguji coba aplikasi yang sudah dibangun.

\section{a. Halaman Utama Web User}

Halaman utama ini merupakan tampilan awal ketika pengunjung (user) mengunjungi web sistem pakar tanaman kedelai. Menu yang ada pada web ini seperti Home, Info Kedelai, Diagnosa dan Tentang. Dapat dilihat pada Gambar 9.

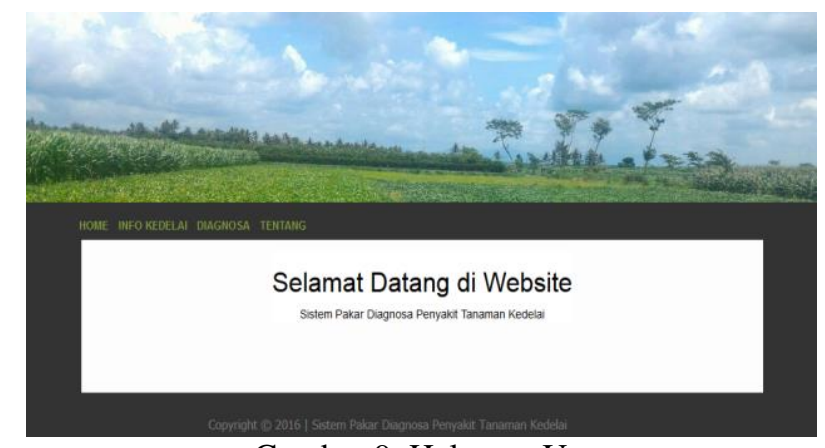

Gambar 9. Halaman Utama

\section{b. Halaman Info Kedelai}

Halaman Info Kedelai merupakan menu dropdown berisikan deskripsi kedelai, penyakit kedelai, pengolahan tanah, pemilihan bibit, dan cara penanaman kedelai Dapat dilihat pada Gambar 10.

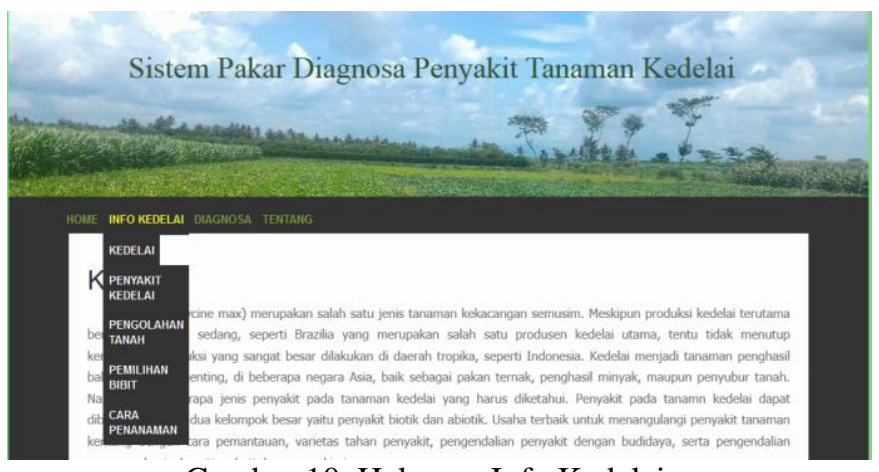

Gambar 10. Halaman Info Kedelai.

\section{c. Halaman Diagnosa}

Halaman Diagnosa merupakan sekumpulan gejala yang akan dipilih oleh user sesuai dengan data yang dimiliki oleh user. Dapat dilihat pada Gambar 11.

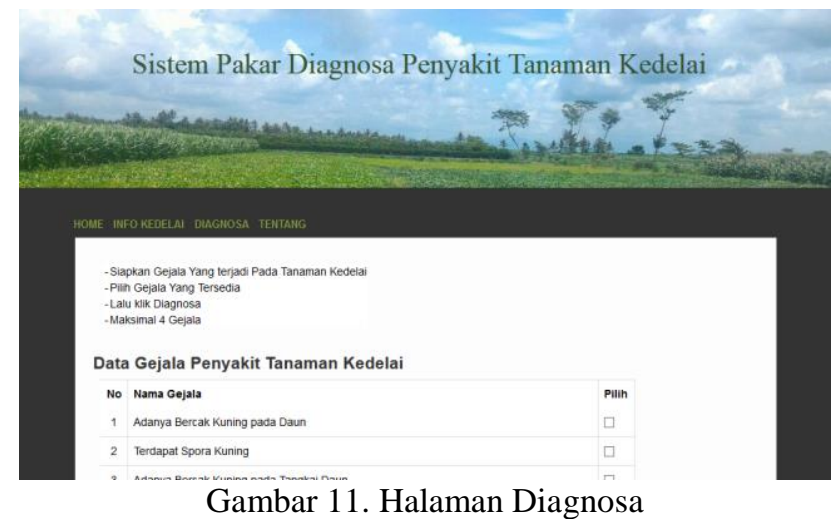




\section{d. Halaman Hasil diagnosa}

Halaman Hasil Diagnosa merupakan hasil diagnosa dari data gejala yang telah dipilih oleh user. Dapat dilihat pada Gambar 12.

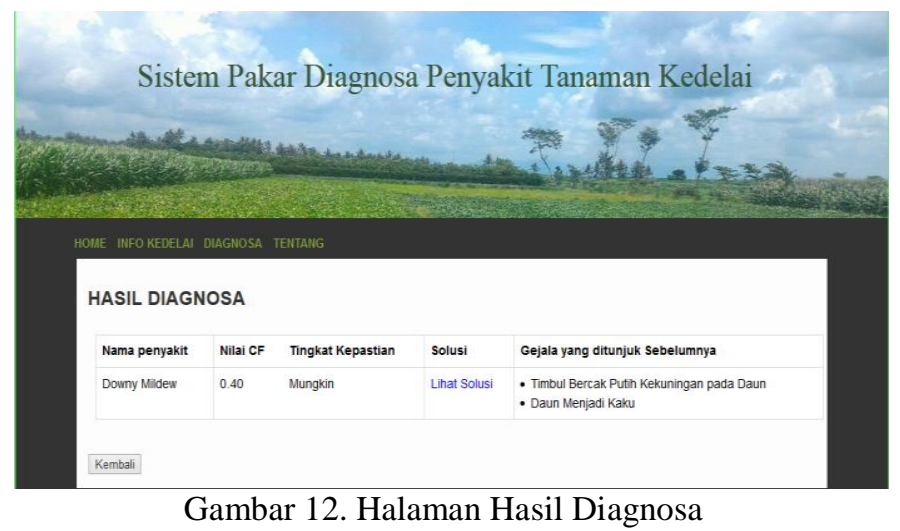

\section{e. Halaman Detail Solusi}

Halaman Detail Solusi merupakan tampilan tentang hasil dari penyakit yang telah di diagnosa. Dapat dilihat pada Gambar 13.

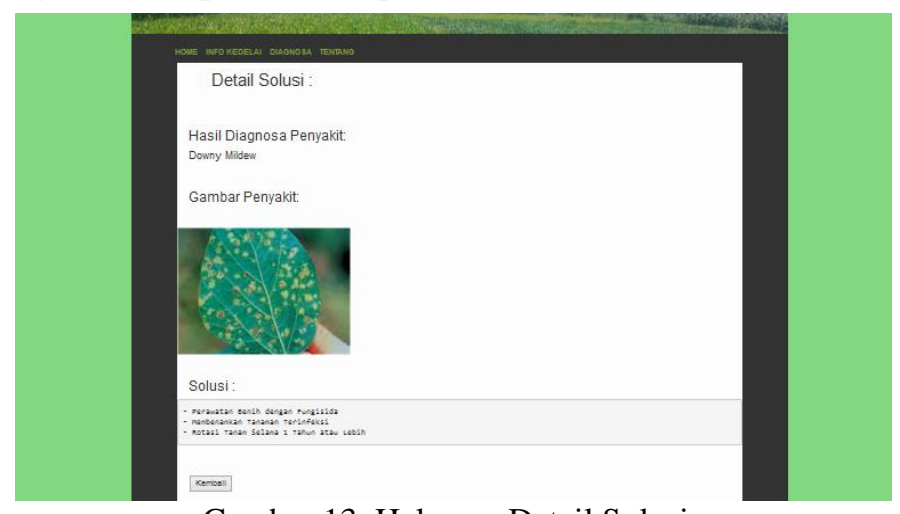

Gambar 13. Halaman Detail Solusi

\section{f. Halaman Awal Admin}

Pada halaman awal admin, maka akan ada beberapa pilihan data yang bisa di ubah, di tambahkan serta di hapus, yaitu data gejala, data penyakit, aturan diagnosa dan data admin. seperti pada Gambar 14.

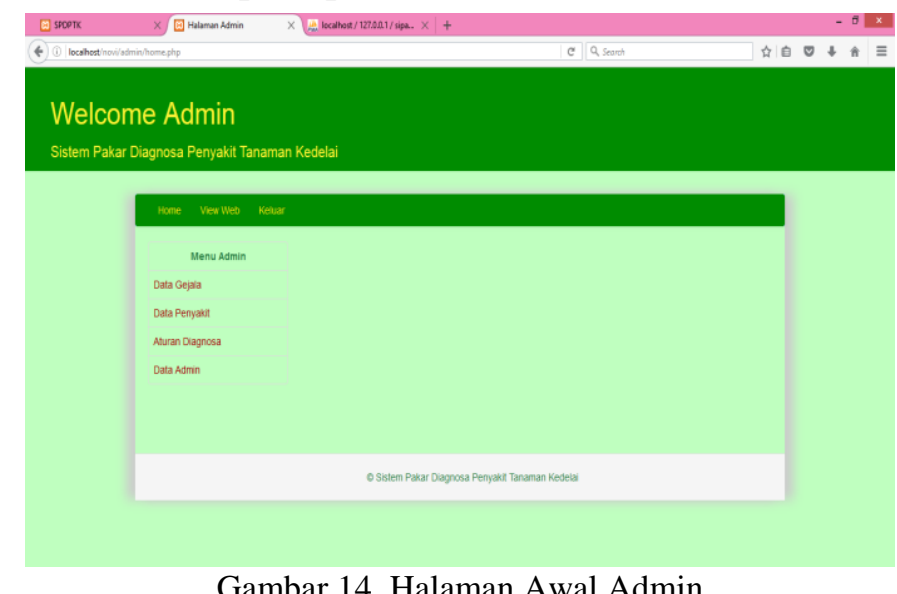

Gambar 14. Halaman Awal Admin 


\section{g. Halaman Admin Data Gejala}

Pada halaman ini admin bisa mengubaht data gejala, menghapus data gejala serta menambahkan data gejala. seperti pada Gambar 15.

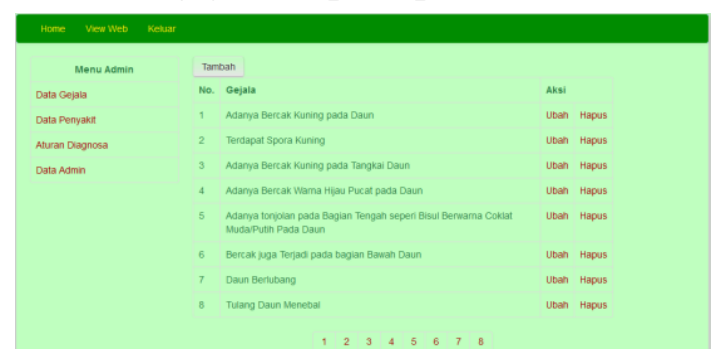

Gambar 15. Halaman Admin Data Gejala

\section{h. Halaman Admin Data Aturan}

Halaman ini merupakan halaman admin yang bisa digunakan oleh admin untuk mengubah aturan, menghapus aturan serta menambahkan aturan. Dapat dilihat pada Gambar 16.

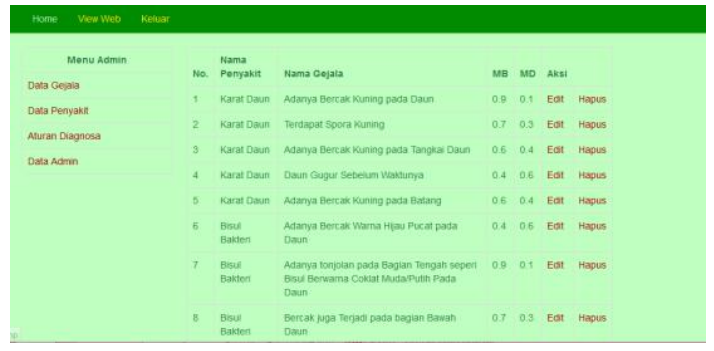

Gambar 16. Halaman Admin Data Aturan

\section{i. Pengujian Perhitungan Metode Certainty Factor}

Berdasarkan penilaian diagnosa sesuai gejala yang ada, maka dapat diperoleh data sebagai berikut.

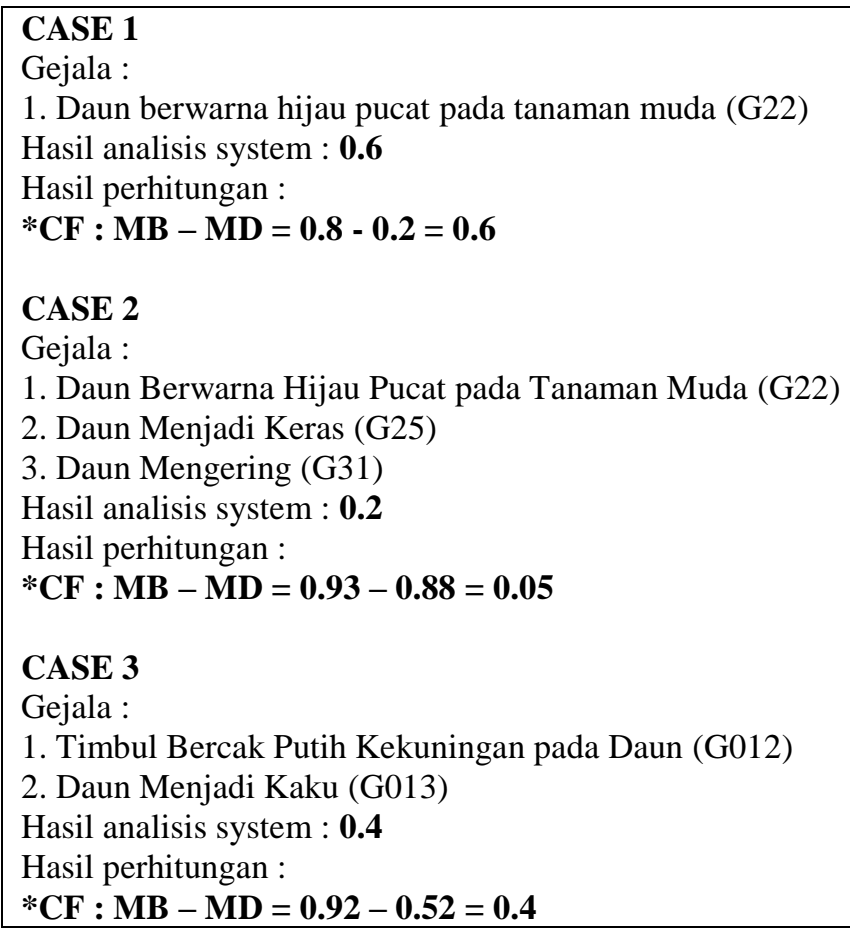


Tabel 1. Pengujian Perhitungan Metode

\begin{tabular}{cccc}
\hline Case & Sistem & Perhitungan & \%error \\
1. & $\mathbf{0 . 6}$ & $\mathbf{0 . 6}$ & $0.6-0.6 / 0.6 * 100 \%=\mathbf{0 \%}$ \\
\hline 2. & $\mathbf{0 . 2}$ & $\mathbf{0 . 0 5}$ & $0.05-0.2 / 0.2 * 100 \%=\mathbf{0 , 8 \%}$ \\
\hline 3. & $\mathbf{0 . 4}$ & $\mathbf{0 . 4}$ & $0.4-0.4 / 0.4 * 100 \%=\mathbf{0 \%}$ \\
\hline \multicolumn{3}{c}{ Rata-rata error } \\
\hline
\end{tabular}

Pada pengujian sistem yang dilakukan untuk menguji keakuratan perhitungan sistem dan analisis perhitungan didapatkan nilai prosentase error tertinggi $0,8 \%$ dan rata-rata eror sebesar $0,27 \%$.

\section{j. Pengujian Tampilan Menu Website}

Pada tahap pengujian aplikasi dilakukan dengan menggunakan 3 browser yaitu Google Chrome, Mozilla Firefox dan Internet Explorer. pengujian ini dilakukan untuk mengetahui fungsional aplikasi berbasis web. Hasil pengujian ditunjukkan pada Tabel 2.

Tabel 2. Pengujian Tampilan Menu Website

\begin{tabular}{|c|c|c|c|c|}
\hline Akses & Fungsi & IE & MF & GC \\
\hline \multirow[t]{8}{*}{ Admin } & $\begin{array}{l}\text { Dapat melakukan login untuk } \\
\text { mengakses halaman admin. }\end{array}$ & $\square$ & $\square$ & $\square$ \\
\hline & Dapat menampilkan data gejala & $\square$ & $\square$ & $\square$ \\
\hline & $\begin{array}{l}\text { Dapat melakukan tambah, edit dan } \\
\text { hapus data gejala }\end{array}$ & $\square$ & $\square$ & $\square$ \\
\hline & Dapat menampilkan data penyakit & $\square$ & $\square$ & $\square$ \\
\hline & $\begin{array}{l}\text { Dapat melakukan tambah, ubah dan } \\
\text { hapus data penyakit }\end{array}$ & $\square$ & $\square$ & $\square$ \\
\hline & Dapat menampilkan data aturan/relasi & $\square$ & $\square$ & $\square$ \\
\hline & $\begin{array}{l}\text { Dapat melakukan tambah, ubah dan } \\
\text { hapus data relasi }\end{array}$ & $\square$ & $\square$ & $\square$ \\
\hline & $\begin{array}{l}\text { Dapat melakukan logout untuk keluar } \\
\text { dari halaman admin }\end{array}$ & $\square$ & $\square$ & $\square$ \\
\hline \multirow[t]{5}{*}{ User } & Dapat melihat halaman beranda & $\square$ & $\square$ & $\square$ \\
\hline & Dapat melihat halaman informasi & $\square$ & $\square$ & $\square$ \\
\hline & $\begin{array}{l}\text { Dapat melakukan diagnosis dengan } \\
\text { cara pilih dengan Checklist gejala - } \\
\text { gejala yang di pilih }\end{array}$ & $\square$ & $\square$ & $\square$ \\
\hline & $\begin{array}{l}\text { Dapat melakukan klik pada button } \\
\text { diagnosa }\end{array}$ & $\square$ & $\square$ & $\square$ \\
\hline & $\begin{array}{l}\text { Dapat melakukan klik pada tombol } \\
\text { diagnosa }\end{array}$ & $\square$ & $\square$ & $\square$ \\
\hline
\end{tabular}

Pada tahap pengujian aplikasi yang dilakukan dengan menggunakan 3 browser yaitu Google Chrome, Mozilla Firefox dan Internet Explorer, semua fungsi dari sistem berjalan sesuai dengan yang diinginkan.

Setelah melakukan pengujian fungsionalitas sistem maka selanjutnya dilakukan pengujian user, pengujian ini dilakukan dengan menyebarkan kuisoner kepada 6 (enam) orang yang berhubungan dengan hasil sistem pakar. 

ini

Dari 6 responden tersebut memberikan hasil seperti pada Tabel 3 berikut

Tabel 3. Pengujian user

\begin{tabular}{lccc}
\hline \multirow{2}{*}{ Pertanyaan } & \multicolumn{3}{c}{ Jawaban } \\
\cline { 2 - 4 } & $\begin{array}{c}\text { Sangat } \\
\text { Setuju }\end{array}$ & Setuju & $\begin{array}{c}\text { Tidak } \\
\text { Setuju }\end{array}$ \\
\hline Aplikasi mudah digunakan & 3 & 3 & - \\
\hline $\begin{array}{l}\text { Tampilan antarmuka Web } \\
\text { Sistem Pakar menarik }\end{array}$ & 2 & 4 & - \\
\hline $\begin{array}{l}\text { Aplikasi dapat membantu } \\
\text { diagnosa Penyakit kedelai }\end{array}$ & 2 & 4 & - \\
\hline Penanganan diagnosa sesuai & 1 & 5 & - \\
\hline $\begin{array}{l}\text { Kesimpulan dan informasi } \\
\text { hasil diagnosa akurat }\end{array}$ & 2 & 3 & 1 \\
\hline Total & 10 & 19 & 1 \\
\hline
\end{tabular}

\section{a. Kesimpulan}

\section{SIMPULAN}

dapat

Dari pembuatan aplikasi berbasis web ini, maka kesimpulan yang diambil adalah sebagai berikut.

1. Hasil Pengujian keakuratan metode baik melalui simulasi program dan perhitungan manual, hasil perhitungan memiliki hasil rata-rata error yang dihasilkan $0.8 \%$.dan nilai eror tertinggi sebesar $0.27 \%$

2. Hasil pengujian fungsional sistem dengan akses sebagai admin dan user semua fungsi berhasil diujikan dengan baik pada browser Internet Explorer, Mozila Firefox, Google Chrome.

3. Pada pengujian kepuasan pengguna dengan prosentase sebanyak $40 \%$ menyatakan bahwa pengguna sangat setuju dan $76 \%$ menyatakan setuju dan 4\% menyatakan bahwa tidak setuju sistem pakar tanaman kedelai ini dapat membantu mendiagnosa penyakit tanaman kedelai.

4. Hasil pengujian pakar yang dilakukan ke hal yang lebih spesifik tentang permasalahan pengetahuan penyakit tanaman kedelai oleh pakar kedelai. Pengujian ini menghasilkan nilai 94 dari skala 100.

\section{b. Saran}

Dari beberapa simpulan yang telah diambil, maka dapat dikemukakan saran-saran yang akan sangat membantu untuk pengembangan perangkat lunak ini selanjutnya.

1. Gejala penyakit tanaman kedelai yang dibahas dalam sistem pakar ini hanya 59 gejala, diharapkan untuk selanjutnya dapat dikembangkan dengan adanya penambahan jumlah gejala dan penyakit yang dibahas.

2. Penambahan halaman cetak laporan hasil diagnosa dan solusi dari konsultasi yang sudah dilakukan 


\section{DAFTAR PUSTAKA}

Destarianto, P., Yudaningtyas, E., \& Pramono, S. H. (2013). Penerapan Metode Inference Tree dan Forward Chaining dalam Sistem Pakar Diagnosis Hama dan Penyakit Kedelai Edamame Berdasarkan Gejala Kerusakannya. Jurnal EECCIS Vol. 7, No. 1, 21-27.

Harto, D. (2013). Perancangan Sistem Pakar untuk Mengidentifikasi Penyakit pada Tanaman Semangka dengan Menggunakan Metode Certainty Factor. Fahma, Volume 8 Nomor 3 , 31-44.

Pratama , Wirandha Ryan; , Jusak; Sudarmaningtya, Pantjawati. (2013). Rancang Bangun Aplikasi Sistem Pakar Untuk Menentukan Penyakit Pada Tanaman Kedelai. JSIKA Vol 2 No (2013)/ISSN 2338-137X, 37-43.

Roja, A. (2012). Rancang Bangun Program Aplikasi Sistem Pakar Untuk Diagnosis Hama Utama Kedelai. Informatika Pertanian, Vol. 21 No.1, 11 26. 